Abstracta Iranica Abstracta Iranica

Revue bibliographique pour le domaine irano-aryen

Volume 40-41 | 2019

Comptes rendus des publications de 2017-2018

\title{
Erica C. D. Hunter, J. F. Coakley. A Syriac Service- Book from Turfān : Museum für asiatische Kunst, Berlin MIK III 45
}

Florence Jullien

\section{(2) OpenEdition Journals}

Édition électronique

URL : http://journals.openedition.org/abstractairanica/50902

DOI : 10.4000/abstractairanica.50902

ISBN : 1961-960X

ISSN : 1961-960X

\section{Éditeur :}

CNRS (UMR 7528 Mondes iraniens et indiens), Éditions de l'IFRI

\section{Référence électronique}

Florence Jullien, «Erica C. D. Hunter, J. F. Coakley. A Syriac Service-Book from Turfān : Museum für asiatische Kunst, Berlin MIK III $45 »$, Abstracta Iranica [En ligne], Volume 40-41 | 2019, document 7, mis en ligne le 30 décembre 2019, consulté le 27 avril 2021. URL : http://journals.openedition.org/ abstractairanica/50902 ; DOI : https://doi.org/10.4000/abstractairanica.50902

Ce document a été généré automatiquement le 27 avril 2021.

Tous droits réservés 


\title{
Erica C. D. Hunter, J. F. Coakley. A Syriac Service-Book from Turfān : Museum für asiatische Kunst, Berlin MIK III 45
}

\author{
Florence Jullien
}

\section{RÉFÉRENCE}

Erica C. D. Hunter, J. F. Coakley. A Syriac Service-Book from Turfān : Museum für asiatische Kunst, Berlin MIK III 45. (Berliner Turfāntexte 39), Turnhout : Brepols, 2017, X p.-307 p., 17 illustr. N\&B, 111 tables N\&B. ISBN 978-2-503-57471-4

1 Les AA. présentent ici pour la première fois l'étude et l'édition critique avec traduction en anglais du manuscrit syriaque MIK III 45 retrouvé sur le site du monastère de Bulayïq près de Turfān. Ce manuscrit de 60 folios, découvert lors de la deuxième expédition allemande à Turfān en 1905, est un livre liturgique datant du VIII ${ }^{\mathrm{e}}-\mathrm{IX}^{\mathrm{e}}$ siècle, correspondant à la Penqita, un livre plus tard connu sous le nom de Hudra. Il contient les offices chrétiens quotidiens et les prières eucharistiques auxquels ont été ajoutés certains offices occasionnels de l'Église d'Orient, notamment les services funéraires. Ce manuscrit constitue le plus ancien témoin connu de la Penqita, dont l'instauration remonte au VII ${ }^{\mathrm{e}} \mathrm{s}$. puisque c'est le patriarche İšōyahb III qui fixa le cadre de l'année ecclésiastique - un modèle toujours en vigueur dans cette Église. Les 60 folios retrouvés ne constituent qu'un quart environ de la totalité du manuscrit - le reste étant perdu. Pour les AA., il aurait probablement été rédigé à Merv à l'attention de la communauté chrétienne syro-orientale de Turfān et serait ainsi l'unique manuscrit syriaque connu en provenance de ce centre chrétien. 


\section{AUTEURS}

\section{FLORENCE JULLIEN}

CNRS, Mondes iranien et indien, Paris 